\title{
Life Meaning: An Important Correlate of Health in the Hungarian Population
}

\section{Árpád Skrabski, Maria Kopp, Sándor Rózsa, János Réthelyi, and Richard H. Rahe}

\begin{abstract}
One of the 5 coping scales in Rahe's Brief Stress and Coping Inventory, entitled Life Meaning, was examined in relation to demographic characteristics, other coping measures, and health status in a sample of 12,640 Hungarian participants. Participants were selected to represent the country's population according to sex, age, and place of residence. The study also explored the contribution of life meaning to the explanation of variations of middle-aged (45-64 years) male and female mortality rates across 150 subregions in Hungary. On an ecological level life meaning proved to be inversely related to male and female oncological, female cardiovascular, and total premature mortality rates in the 150 subregions of Hungary and on an individual level to participants' reported health status. In the total sample of individuals after controlling for gender, age, and education, life meaning scores showed strong correlations with the World Health Organization well-being scale, with self-rated absence of depression, with self-rated health, and with self-rated absence of disability. Although relatively unrelated to age, gender, and education, life meaning was positively related to self-efficacy, importance of religion, problem-oriented coping, and social support.
\end{abstract}

Key words: life meaning, premature oncological mortality, premature cardiovascular mortality, self-rated health, well-being, depression, self-efficacy, spirituality, religion, ways of coping, social support

In modern-day Central-Eastern European countries, there is a morbidity and mortality crisis, involving chiefly the middle-aged population. (Cornia \& Panicia, 2001). Up through the end of the 1970s, mortality rates in Hungary were lower than those observed in Great Britain or Austria. Subsequently, mortality rates de-

Árpád Skrabski, Vilmos Apor Catholic College, Vác, Hungary; Maria Kopp, János Réthelyi, Institute of Behavioural Sciences, Semmelweis University, Budapest, Hungary; Sándor Rózsa, Institute of Psychology, Eötvös Loránt University, Budapest, Hungary; Richard H. Rahe, Veterans Affairs Puget Sound Health Care System, American Lake Division, Tacoma, WA, USA

The authors would like to thank Professor Gail Ironson and Professor Lynda Powell for their valuable advice and suggestions for the improvement of the manuscript; the other members of the "Hungarostudy 2002" team (Adrienne Stauder, Csilla Csoboth, Éva Susánszky, György Gyukits, János Lőke, Andrea Ódor, András Székely, and László Szúcs); the network of district nurses for the home interviews; Professor András Klinger for the sampling procedure; and especially to Katalin Hajdu, Csilla Raduch, and Noémi Somorjai for valuable assistance in the study. This study was supported by the United Nations Development Program (UNDP) project No. HUN/00/002/A/01/99, the National Research Fund (OTKA) projects No. T-32974 (2000), OTKA TS-40889 (2002), and T (2004) Scientific School grant, NKFP 1/002/2001 and NKFP $1 \mathrm{~b} / 020 / 2004$.

Correspondence concerning this article should be addressed to Professor Maria Kopp, Institute of Behavioural Sciences, Semmelweis University Budapest, H-1089 Budapest, Nagyvárad tér 4, Hungary. E-mail: kopmar@net.sote.hu clined in Western Europe. However, in Hungary and in other Central-Eastern European countries this trend was reversed, especially among middle-aged men. In the late $1980 \mathrm{~s}$, the mortality rates among 45- to 64-year-old men in Hungary rose to and remained at levels that were higher than they were in the 1930s (Demographic Yearbook, 2002; Kopp \& Réthelyi, 2004; Kopp, Skrabski, \& Szedmák, 2000; Skrabski, Kopp, \& Kawachi, 2003, 2004). Between 1970 and 1990 , mortality rates increased from 12.5 to 15.5 per thousand for men and from 10.8 to 12.8 per thousand for women (Demographic Yearbook, 2002; Kopp, Skrabsky, \& Székely, 2002). In Hungarian persons younger than 65 years, the standardized mortality rates for cardiovascular disorders are three times higher and for oncological disorders twice as high as the European average. In Hungary, deaths due to neoplasms are among the highest in international comparisons (Gárdos, 2002).

The most popular explanations for health trends in Central-Eastern Europe do not provide an explanation for these sudden changes in health status (Cornia \& Panicia, 2001). Thus, there is a need for new approaches to understanding the processes of health deterioration in societies in transition. In a recent review, Pikó and Fitzpatrick (2004) suggested that understanding and solving the Central-Eastern European health crisis required creative psychological approaches. 
Premature mortality is the most dramatic measure of poor health in a society. However, a broader concept of health is to view it as a dynamic equilibrium. The World Health Organization (WHO) definition of health emphasizes the importance of mental and social well-being (WHO, 2001). This concept, by definition, draws on the contributions of positive psychology, which aim to understand and reinforce human strengths and factors that allow individuals, communities, and societies to flourish (Seligman \& Csikszentmihályi, 2000).

Empirical evidence suggests beneficial health effects from individuals' spiritual beliefs and practices. Spirituality appears to be an important resource for health and one that is not easily reducible to other social and behavioral factors such as social support and socioeconomic status (for reviews see Astrow, Puchalsky, \& Sulmasy, 2001; Oman \& Thoresen, 2003; Powell, Shahabi, \& Thoresen, 2003). Spirituality is a broader concept than religion, not limited to those who practice some religious tradition, and is frequently about a search for transcendent meaning (Astrow et al., 2001; Powell et al., 2003).

The Life Meaning subscale of Rahe's Brief Stress and Coping Inventory examines one component of spirituality (Appendix). Some questions are similar to the meaningfulness component of Antonovsky's (1993) Sense of Coherence questionnaire. However, it also includes questions related to the transcendent meaning of life, such as "I feel my life is part of a larger plan" and "My values and beliefs guide me daily."

There were two aims of this study. First, we aimed to determine the relation between Rahe's life meaning construct and self-reported health in a large, representative sample of the Hungarian population. Second, we aimed to determine the ecologic variation between life meaning scores and rates of total, cardiovascular, and oncological morality in middle-aged men and women living in 150 subregions in Hungary.

\section{Methodology}

\section{Sample}

The Hungarostudy 2002 is a national, cross-sectional survey that is representative of the Hungarian population older than 18 years according to sex, age, and the 150 subregions in the country. The sampling was carried out using the National Population Register, which was updated using the 2001 National Census. A clustered, stratified sampling procedure was developed by experts at the National Population Register. All communities with a population of more than 10,000 were included in the sample as well as a randomly selected sample of smaller villages. In a second step, single persons were selected from this data- base in an age and gender distribution that was comparable to that existing in the specific county or settlement size from which they were drawn. The final sample thus reflected the gender, age, and settlement size characteristics of each given county. Two random samples of 13,000 persons were generated. The first sample was used for the study, and the second sample allowed for replacements of individuals in the first sample who refused to participate.

In 2002, 12,643 persons were interviewed in their homes (Rózsa et al., 2003; Skrabski et al., 2004). The sample represented $0.16 \%$ of the population older than age 18 . The refusal rate was $17.7 \%$. There were differences in refusals based on residence where refusals tended to be higher in large cities than in small villages and based on gender where refusals were $4 \%$ higher in men than in women. For each refusal, another person was selected of the same age and sex from the same community. This replacement procedure did not result in any significant selection bias. The final sample corresponded well to the population descriptors of the Central Statistical Office. We compared the distributions of selected important variables in the final dataset and in the original. The sampling error in each case was within statistically acceptable limits with the highest estimated stratification error being $2.2 \%$ in men aged 18-39. This error is within the limits of the permitted statistical deviation (Rózsa et al., 2003).

The interviewers in this study were district nurses, and the time spent in the homes administrating the questionnaires was approximately $1 \mathrm{hr}$ each (Skrabski et al., 2004). Because of their education in health, district nurses were selected as the most competent persons for interviewing our participants. These nurses were intensively trained for their duties over a 2 -week period, including personal supervision and three test interviews before they began data collection.

\section{Standardized Mortality Data}

Ecological mortality analyses drew on age-standardized, midlife (45 -64 years), gender-specific mortality rates for the main causes of death computed by the Central Statistical Office of Hungary for each of the 150 Hungarian subregions for the last available years, between 2001 and 2003 (Klinger, 2003). The standardized, weighted cardiovascular (ICD 10, 100-199), oncological (ICD 10, C00-D48), and total mortality rates were included as outcome measures.

\section{Measures}

Life meaning. The Hungarian translation of this eight-item subscale from the Brief Stress and Coping Inventory of Richard Rahe (Rahe et al, 2002; Rahe \& Tolles, 2002; Rahe, Veach, Tolles, \& Murakami, 2000) was included in the analyses (See Appendix). 
Cronbach's $\alpha$ for this scale was 0.69 in this study, indicative of acceptable internal consistency (Rózsa et al., 2003). The life meaning score was normally distributed in the sample $(0=$ lowest score, $16=$ maximal score).

Depression. Depressive symptomatology was measured by the nine-item shortened version of the Beck Depression Inventory (BDI). This is a reliable measure for screening depressive symptom severity in community surveys (Kopp \& Skrabski, 1996; Kopp et al., 2000; Lasa, Ayuso-Mateos, Vazquez-Barquero, Diez-Manrique, \& Dowrick, 2000; Rózsa, Szádóczky, \& Füredi, 2001). In this study the internal consistency for this scale was 0.85 (Rózsa et al., 2003). The Hungarian version of this scale was validated in the general population and on clinical samples earlier (Rózsa et al., 2001; 0 = lowest score, 27 = maximal score $)$.

WHO Well-Being Scale. This five-item measure of well-being had a Cronbach's $\alpha$ of 0.84 in this study (Bech, Staehr-Johansen, \& Gudex, 1996; Rózsa et al., 2003; $0=$ lowest score, $15=$ maximal score) .

Self-Efficacy questionnaire. Cronbach's $\alpha$ for this four-item scale in this study was 0.83 (Kopp, Schwarzer, \& Jerusalem, 1993; Rózsa et al., 2003; Schwarzer, 1993; $0=$ lowest score, $12=$ maximal score).

Shortened version of Ways of Coping questionnaire. The 16-item shortened version of the Ways of Coping questionnaire (Folkman \& Lazarus, 1980; Kopp \& Skrabski, 1996; Rózsa et al., 2003) features problem-focused coping $(0=$ lowest score, $18=$ maximal score), emotion-focused coping ( $0=$ lowest score, $24=$ maximal score $)$, and support seeking $(0=$ lowest score, $6=$ maximal score) factors (Rózsa et al., in press; Skrabski et al., 2004). Cronbach's $\alpha$ for the total score was 0.71 in this study (Rózsa et al., 2003).

Perceived social support. This scale measured perceived support separately as support from family members $(0=$ no support, $15=$ maximal support $)$; from nonfamily members $(0=$ no support, $12=$ maximal support); and from civic associations, religious associations, or both $(0=$ no support, $6=$ maximal support; Caldwell, 1987; Kopp \& Skrabski, 1996; Kopp et al., 2000). Each type of support was scored from 0 to 3 , indicating the degree of perceived support ranging from none to a great deal.

Subjectively rated health (SRH) and self-reported disability (SRD). SRH was measured with the question "How do you rate your health in general?" There were five responses: very good, good, fair, poor, and very poor. Self-reported absence of SRD was mea- sured by the question "How do you rate your working disability?" There were six response options: no working disability, light working disability, medium working disability, severe working disability, not able to work, and cannot leave his or her chair or bedridden.

Religious involvement and importance of religion. Involvement in religion was measured by two questions: "Are you religious? If yes, what is the form of your worship?" Responses to the first question were scored 0 for "I am not religious," 1 for "I don't worship," 2 for "I worship in my own way," 3 for "I worship rarely in my church," and 4 for "I worship regularly in my church." The second question related to the importance of religion was scored 0 for "Not at all," 1 for "Slightly," 2 for "Very important," and 3 for "It influences my every action."

Demographic control variables. Education was measured by the highest education grade on a six-level score (from less than primary to university level). Sex ( $1=$ men, 2 = women $)$ and age of the persons were included.

\section{Statistical Methods}

SPSS (1999) Base 9 was used for all analyses. Cronbach $\alpha$ coefficients, partial correlation analyses, and multiple stepwise linear regression analyses with standardized $\beta$ weights were used. Partial correlation coefficients, adjusting for age, sex, and education, were calculated between life meaning and self-rated health, self-rated freedom from disability, and the other psychosocial variables on an individual level. Regression models were constructed to examine life meaning jointly with the other demographic and psychosocial variables as correlates of the various self-reported health dependent variables. For the ecological analyses, the average values of life meaning scores were computed for each of the 150 Hungarian subregions, separately for men and women, and then correlated with gender- and disease-specific mortality rates for each of these subregions.

\section{Results}

Table 1 presents the results of the ecological analyses that link average life meaning scores to standardized subregional mortality rates in each of the 150 subregions in Hungary (weighted by number of cases; men and women in 45-64 year age group; $n=4,265$, female $=2,274$, male $=1,991)$. Life meaning was inversely related to premature total and oncological mortality for both men and women. For cardiovascular mortality, life meaning was inversely related only for the women. Male total premature mortality and male cardiovascu- 
LIFE MEANING

Table 1. Ecological Correlations Between Standardized Oncological, Cardiovascular, and Total Mortality Rates and Average Life Meaning Scores in 150 Hungarian Subregions, in 45-64 Year-Old Men and Women

\begin{tabular}{llccc}
\hline & \multicolumn{1}{c}{ Average Male Life Meaning } & \multicolumn{2}{c}{ Average Female Life Meaning } \\
\hline Male oncological mortality & $r=-.190$, & $p<0.000$ & $r=-.185$, & $p<0.000$ \\
Male cardiovascular mortality & $r=-.011$, & $\mathrm{ns}$ & $r=-.056$, & $p<0.000$ \\
Male total mortality & $r=-.089$, & $p<0.000$ & $r=-.108$, & $p<0.000$ \\
Female oncological mortality & $r=-.043$, & $p<0.005$ & $r=-.032$, & $p<0.038$ \\
Female cardiovascular mortality & $r=-.039$, & $p<0.010$ & $r=-.110$, & $p<0.000$ \\
Female total mortality & $r=-.029$, & $\mathrm{ns}$ & $r=-.062$, & $p<0.000$ \\
\hline
\end{tabular}

Note. Weighted by number cases, men and women in $45-64$ years age group. $n=4,265$, male 1,991 , female 2,274 . ns= not significant.

lar mortality were more closely connected with female life meaning than with male life meaning.

Table 2 presents the results of the individual level analyses linking life meaning to self-reported health. After controlling for the effects of gender, age and education, life meaning was most closely connected with

Table 2. Partial Correlations Between Life Meaning and Self-Reported Health

\begin{tabular}{llr}
\hline & \multicolumn{2}{c}{ Life Meaning Score } \\
\hline WHO well-being & $r=.349^{\mathrm{a}}$ & $p<0.000$ \\
Self-rated absence of depression & $r=.261^{\mathrm{a}}$ & $p<0.000$ \\
Self rated health & $r=.172^{\mathrm{a}}$ & $p<0.000$ \\
Self-rated freedom from disability & $r=.118^{\mathrm{a}}$ & $p<0.000$ \\
\hline
\end{tabular}

Note. $\quad n=12,640 . \mathrm{WHO}=$ World Health Organization.

${ }^{\mathrm{a}}$ Controlled for sex, age, and education.
WHO well-being score $(r=.349)$, next with the selfrated absence of depression $(r=.261)$, with self-rated health $(r=.172)$, and with self-rated absence of disability $(r=.118)$. All correlations were highly significant $(p$ $<0.000)$.

Tables 3-5 present the results of the regression analyses that examine the independent correlates of well-being, depression, and self-rated health, respectively. Table 3 shows that the most important correlate of WHO well-being was life meaning where the $\beta$ weight (.27) was more than twice that of the next strongest variable (age) to enter the equation. Table 4 shows that the three most important correlates of BDI depression were life meaning $(\beta=-.20)$, age $(\beta=$ $.22)$, and emotion-focused coping $(\beta=.26)$. Table 5 shows that the most important correlate of self-rated health was age $(\beta=-.42)$. After age and education, life meaning entered third in the model $(\beta=.11)$.

Table 3. Independent Correlates of WHO Well-Being Score

\begin{tabular}{lcccc}
\hline Stepwise Linear Regression & Standardized $\beta \mathbf{s}$ & $\boldsymbol{t}$ & Sig. & $\begin{array}{c}\text { Adjusted R Squared for } \\
\text { the Final Model }\end{array}$ \\
\hline Life meaning & .27 & 24.99 & $<0.000$ & 12 \\
Age & -.14 & -13.56 & $<0.000$ & 16 \\
Problem-focused coping & .12 & 11.32 & $<0.000$ & 17 \\
Emotion-focused coping & -.11 & -11.43 & $<0.000$ & 18 \\
Perceived help, not from relatives & .07 & 6.76 & 0.000 & 19 \\
Sex & -.08 & -8.35 & $<0.000$ & 19 \\
Education & .06 & 6.48 & $<0.000$ & 20 \\
Perceived help from family & .03 & 3.12 & $<0.001$ & 20 \\
\hline
\end{tabular}

Notes. $n=12,640 . \mathrm{WHO}=$ World Health Organization.

Table 4. Independent Correlates of Shortened Beck Depression Score

\begin{tabular}{lcccc}
\hline Stepwise Linear Regression & Standardized $\beta \mathbf{s}$ & $\boldsymbol{t}$ & Sig. & $\begin{array}{c}\text { Adjusted R Squared for } \\
\text { the Final Model }\end{array}$ \\
\hline Life meaning & -.20 & -18.81 & $<0.000$ & .07 \\
Age & .22 & 22.03 & $<0.000$ & .13 \\
Emotion-focused coping & .26 & 26.19 & $<0.000$ & .20 \\
Education & -.16 & -16.30 & $<0.000$ & .23 \\
Perceived help, not from relatives & -.06 & -6.59 & $<0.000$ & .23 \\
Sex & .05 & 5.26 & $<0.000$ & .24 \\
Perceived help from civic or & .04 & 4.59 & $<0.000$ & .24 \\
religious association & & & & .24 \\
Perceived help from family & -.04 & -4.12 & $<0.000$ & .24 \\
Problem-focused coping & -.03 & -2.96 & $<0.001$ & \\
\hline
\end{tabular}

Note. $n=12,640$. 
Table 5. Independent Correlates of Self-Rated Health

\begin{tabular}{lcccc}
\hline Stepwise Linear Regression & Standardized $\beta \mathbf{s}$ & $\boldsymbol{t}$ & Sig. & $\begin{array}{c}\text { Adjusted R Squared for } \\
\text { the Final Model }\end{array}$ \\
\hline Age & -.42 & -43.27 & $<0.000$ & .21 \\
Education & .15 & 16.37 & $<0.000$ & .25 \\
Life meaning & .11 & 10.84 & $<0.000$ & .27 \\
Emotion-focused coping & -.11 & -12.37 & $<0.000$ & .28 \\
Perceived help, not from relatives & .06 & 6.14 & $<0.000$ & .29 \\
Problem-focused coping & .04 & 4.46 & $<0.000$ & .29 \\
Sex & -.03 & -3.85 & $<0.000$ & .29 \\
\hline
\end{tabular}

Note. $n=12,640$

Table 6 presents the partial correlations between life meaning and the other psychosocial variables, adjusting for sex, age, and education. Life meaning was most strongly related to self-efficacy $(r=.438)$, but all of the other psychosocial variables were also significantly correlated. There was a connection between life meaning and both practice of religion $(r=.187)$ and importance of religion $(r=.221)$.

Table 7 presents a multivariate model that examines the independent correlates of life meaning. Self-efficacy, importance of religion, problem-focused coping,

Table 6. Partial Correlations Between Life Meaning and Other Psychosocial Variables

\begin{tabular}{lll}
\hline & \multicolumn{2}{c}{ Life Meaning Score } \\
\hline Self-efficacy & $r=.438^{\mathrm{a}}$ & $p<0.000$ \\
Problem-focused coping & $r=.339^{\mathrm{a}}$ & $p<0.000$ \\
Emotion-focused coping & $r=-.091^{\mathrm{a}}$ & $p<0.000$ \\
$\begin{array}{l}\text { Perceived social support from } \\
\quad \text { relatives }\end{array}$ & $r=.169^{\mathrm{a}}$ & $p<0.000$ \\
$\begin{array}{l}\text { Perceived social support, not from } \\
\quad \text { relatives (friends, coworkers, }\end{array}$ & $r=.221^{\mathrm{a}}$ & \\
$\quad$ neighbors) & & \\
$\begin{array}{l}\text { Perceived social support from civic } \\
\quad \text { organizations }\end{array}$ & $r=.191^{\mathrm{a}}$ & \\
$\begin{array}{l}\text { Importance of religion } \\
\text { Practice of religion }\end{array}$ & $r=.221^{\mathrm{a}}$ & $p<0.000$ \\
\hline
\end{tabular}

Note. $n=12,640$.

${ }^{\mathrm{a} C o n t r o l l e d ~ f o r ~ s e x, ~ a g e, ~ a n d ~ e d u c a t i o n . ~}$ and perceived social support from nonrelative and from family were most closely connected with life meaning. Sex, age, and education were less closely related. Together, the set of variables explained $33.6 \%$ of the variance of life meaning in the total population.

\section{Discussion}

Life meaning, as measured by the Rahe Brief Stress and Coping Inventory, proved to be strongly related to the self-reported health status of this large, nationally representative sample of the Hungarian population. On an ecological level, life meaning was also related to premature mortality trends in the 150 subregions of Hungary. Interestingly, male premature mortality and male cardiovascular mortality were more closely connected to female life meaning scores than to male life meaning scores. These results are consistent with our previous findings that male and female health are strongly interconnected but that female attitudes appear to influence male health more strongly than the male attitudes influence female health (Kopp et al., in press; Skrabski et al., 2003).

Self-rated health is a reliable predictor of morbidity and mortality. Several studies have shown an increased risk of death in those who report that their health is poor (Idler \& Benjamini,1997; Kaplan et al., 1996; Miilunpalo, Vuori, Oja, Pasanen, \& Urponen, 1997;

Table 7. Independent Correlates of Life Meaning

\begin{tabular}{|c|c|c|c|c|}
\hline Stepwise Linear Regression & Standardized $\beta$ s & $t$ & Sig. & $\begin{array}{c}\text { Adjusted R Squared for } \\
\text { the Final Model }\end{array}$ \\
\hline Self-efficacy & .337 & 34.7 & $<0.000$ & .198 \\
\hline Importance of religion & .172 & 16.7 & $<0.000$ & .248 \\
\hline Problem-focused coping & .226 & 22.3 & $<0.000$ & .292 \\
\hline Social support not from relatives & .104 & 10.5 & $<0.000$ & .307 \\
\hline Emotion-focused coping & -.105 & -11.1 & $<0.000$ & .320 \\
\hline Social support from family & .093 & 10.1 & $<0.000$ & .329 \\
\hline Social support from religious or civic groups & .057 & 5.7 & $<0.000$ & .331 \\
\hline Sex & .043 & 4.7 & $<0.000$ & .333 \\
\hline Age & .049 & 4.9 & $<0.000$ & .334 \\
\hline Education & .045 & 4.7 & $<0.001$ & .336 \\
\hline
\end{tabular}

Note. $n=12,640$. 
Moller, Kristenson, \& Hollnagel, 1996; Wannamethee $\&$ Shaper, 1991). In a separate study, we examined the ecological associations between self-rated health and middle-aged (45-64 years) mortality rates across the 20 counties of Hungary. We found that self-rated health at the aggregate level is strongly correlated with mortality rates in both men and women, although more strongly for the former than for the latter (Kopp et al., 2004, in press).

Depression is an independent risk factor for mortality, especially among men (Hemingway \& Marmot, 1999; Kubzansky \& Kawachi, 2000; Musselman, Evans, \& Nemeroff, 1998). Glassman and Shapiro (1998) reviewed the relation between depression and cardiovascular morbidity and mortality. After controlling for smoking and other standard risk factors (gender, weight, activity, blood pressure, and cholesterol), the apparently healthy individuals who had elevated depression ratings were more likely both to develop and to die from ischemic heart disease. The results of five longitudinal studies showed that people with serious depression, and with no cardiovascular disease at the beginning of the study, were two to four times more likely to die of myocardial infarction. This relation held when these data were standardized for other known risk factors (Glassman \& Shapiro, 1998; Murphy, Monson, Olivier, Sobol, \& Leighton, 1987; Musselman et al., 1998; Pratt et al., 1996). Depression can make the course of other disorders, such as cancer, diabetes, immunological diseases, and osteoporosis, more serious and accelerate aging (Dinan, 1999; Horrobin \& Bennett, 1999; Kielkolt-Glaser, 2002).

Consequently, our results suggest that meaning in life is an important salutogenic factor in population health, particularly in a society undergoing considerable political and economic transition. The self-efficacy concept (Bandura, 1997; Schwarzer, 1993) is a well-documented positive psychology component, but life meaning was more closely connected to reported good health in our study. Life meaning was, in fact, correlated with a number of positive psychosocial factors, including self-efficacy, problem-focused coping, religiousness, and high levels of social support. Interestingly, life meaning was independent of age, gender, and education.

There is a scholarly neglect of the empowering functions of spirituality in the Western world (Oman \& Thoresen, 2003). There are few studies on the health effects of the oppression against spirituality and religion in the communist countries under the Soviet rule. Religion was regarded as "the opium of the people" and Marxist "scientific materialism" was a requirement for university entrance examinations as well as for positions in education, science, and public affairs. Religious practices and expression of spiritual thinking were punished. It can be hypothesized that there were ill-health effects secondary to this strong opposition of religion and spirituality. These proposed effects might be called "cultural iatrogenesis," which diminished the capacities of people to cope positively with difficulties of life (Oman \& Thoresen, 2003).

Recent political changes and the uncritical acceptance of Western consumer values in the Hungarian population might also contribute to the health deterioration of the male population. Interestingly, in the older age groups (older than 65 years), the Hungarian health statistics are better than they are in the middle-aged population. Nonetheless, the Hungarian statistics are comparable to the worst Western European figures in the elderly age groups (Demographic Yearbook, 2002; Kopp et al., 2002). The Hungarian health deterioration has been more marked among men than among women in the last decade. Both life meaning and religiousness are higher in women (Kopp et al., 2004). Religious involvement may be a strong protective factor for the female Hungarian population (Skrabski et al., 2004). It is important to stress, however, that religion and life meaning are not identical concepts. There are religious people with relatively low life meaning and nonreligious people with high life meaning. Thus, life meaning seems to be an independent positive psychological health protective factor, yet one that is closely connected with spirituality and the search for transcendent meaning in life (Astrow et al., 2001).

Meaning in life appears to be a positive psychological resource that promotes health in the Hungarian population. It is possible that a similar finding would emerge from studies of other transitioning societies in Central-Eastern Europe. We encourage the incorporation of life meaning into other large-scale studies of stress, coping, and health in such countries in transition.

\section{APPENDIX \\ Life Meaning From Rahe's Brief Stress and Coping Inventory}

Answers: $0=$ no, $1=$ sometimes, $2=$ frequently

I feel my life is part of a larger plan My life has no direction and meaning (reverse coded)

Many things in life give me great joy

I am able to forgive myself and others

I doubt that my life makes a difference (reverse coded)

My values and beliefs guide me daily I feel in tune with people around me I am at peace with my place in life

Source: NEED SOURCE NOTE 


\section{References}

Antonovsky, A. (1993). The structure and properties of the Sense of Coherence Scale. Social Science \& Medicine, 36, 725-733.

Astrow, A. B., Puchalsky, Ch. M., \& Sulmasy, D. P. (2001). Religion, spirituality, and health care: Social, ethical, and practical considerations. American Journal of Medicine, 110, 283-287.

Bandura, A. (1997). Self-Efficacy: The exercise of control. New York: Freeman.

Bech, P., Staehr-Johansen, K., \& Gudex, C. (1996). The WHO (Ten) Well-Being Index: Validation in diabetes. Psychotherapy and Psychosomatics, 65, 183-190.

Caldwell, R. A., Pearson, J. L., \& Chin, R. J. (1987). Stress-moderating effects: Social support in the context of gender and locus of control. Personality and Social Psychology Bulletin, 13, 5-17.

Cornia, A. G., \& Panicci, R. (2001). The mortality crisis in transitional economies. Oxford: Oxford University Press.

Demographic yearbook of Hungary 2002. Budapest: Central Statistical Office.

Dinan, T. G. (1999). Physical consequences of depression. British Medical Journal, 318, 826.

Folkman, S., \& Lazarus, R. S. (1980). An analysis of coping in a middle aged community sample. Journal of Health and Social Behavior, 21, 219-239.

Gárdos, É. (2002). Health status of population. Budapest, Hungary: Central Statistical Office.

Glassman, A. H., \& Shapiro, P. A. (1998). Depression and the course of coronary artery disease. American Journal of Psychiatry, $155,4-11$

Hemingway, H., \& Marmot, M. (1999). Evidence-based cardiology: Psychosocial factors in the aetiology and prognosis of coronary heart disease: Systematic review of prospective cohort studies. British Medical Journal, 318, 1460-1467.

Horrobin, D. F., \& Bennett, C. N. (1999). Depression and bipolar disorder: Relationships to impaired fatty acid and phospholipid metabolism and to diabetes, cardiovascular disease, immunological abnormalities, cancer, ageing and osteoporosis. Prostaglandins, Leukocytes and Essential Fatty Acids, 60, 217-234.

Idler, E. L., \& Benyamini, Y. (1997). Self-rated health and mortality: A review of twenty-seven community studies. Journal of Health and Social Behavior, 38, 21-37.

Kaplan, G. A., Goldberg, D. E., Everson, S. A., Cohen, R. D., Salonen, R., Tuomilehto, J., \& Salonen, J. (1996). Perceived health status and morbidity and mortality: Evidence from the Kuopio Ischemic Heart Disease Risk Factor Study. International Journal of Epidemiology, 25, 1-7.

Kielcolt-Glaser, J. K., McGuire, L., Robles, T. F., \& Glaser, R. (2002). Emotions, morbidity and mortality: New perspective from psychoneuroimmunology. 53, 83-107.

Klinger, A. (2004). Age-standardised midlife (45-64 years) male and female mortality rates in the Hungarian sub-regions in 2001-2003. Report. Budapest, Hungary: Central Statistical Office.

Kopp, M. S., Csoboth, Cs., \& Réthelyi, J. (2004). Psychosocial determinants of premature health deterioration in a changing society: The case of Hungary. Journal of Health Psychology, 9, 99-109.

Kopp, M., Falger, P., Appels, A., \& Szedmák, S. (1998). Depression and vital exhaustion are differentially related to behavioural risk factors for coronary heart disease. Psychosomatic Medicine, 60, 752-758.

Kopp, M. S., \& Réthelyi, J. (2004) Where psychology meets physiology: Chronic stress and premature mortality-the Central-Eastern-European health paradox. Brain Research Bulletin, 62, 351-367.

Kopp, M. S., Schwarzer, R., \& Jerusalem, M. (1993). Hungarian questionnaire in psychometric scales for cross-cultural self-efficacy research. Zentrale Universitats Druckerei der FU Berlin.
Kopp, M. S., \& Skrabski, Á. (1996). Behavioural sciences applied to a changing society. Budapest, Hungary: Biblioteca Septem Artium Liberalium.

Kopp, M. S., Skrabski Á., Réthelyi, J., Kawachi, I., \& Adler, N. E. (2004). Self rated health, subjective social status and middle-aged mortality in a changing society. Behavioral Medicine, 30(2), 65-70.

Kopp, M. S., Skrabski, Á., \& Szedmák, S. (2000). Psychosocial risk factors, inequality and self-rated morbidity in a changing society. Social Sciences and Medicine, 51, 1350-1361.

Kopp, M., Skrabski, Á., \& Székely, A. (2002). Risk factors and inequality in relation to morbidity and mortality in a changing society. In G. Weidner, M. S. Kopp, \& M. Kristenson (Eds.), Heart disease: Environment, stress and gender (pp. 101-113). IOS Press, NATO Science Series, Life and Behavioural Sciences 327.

Kopp, M. S., Szekely, A., \& Skarbski, Á. (2004). Religion and health in a changing society. Mentálhigiéné és Pszichoszomatika, 5(2), 103-126. (in Hungarian)

Kubzansky, L. D., \& Kawachi, I. (2000): Going to the heart of the matter: Do negative emotions cause coronary heart disease? Journal of Psychosomatic Research, 48, 323-337.

Lasa, L., Ayuso-Mateos, J. L., Vazquez-Barquero, J. L., Diez-Manrique, F. J., \& Dowrick, C. F. (2000). The use of Beck Depression Inventory to screen for depression in the general population. Journal of Affective Disorders, 57, 261-265.

Miilunpalo, S., Vuori, I., Oja, P., Pasanen, M., \& Urponen, H. (1997). Self-rated health status as a health measure: The predictive value of self-reported health status on the use of physician services and on mortality in the working age population. Journal of Clinical Epidemiology, 50, 517-528.

Miller, W., \& Thoresen, C. E. (2003). Spirituality, religion and health: An emerging research field. American Psychologist, 58, 24-35.

Moller, L., Kristenson, T. S., \& Hollnagel, H. (1996). Self rated health as a predictor of coronary heart disease in Copenhagen, Denmark. Journal of Epidemiology and Community Health, 50, 423-428.

Murphy, J. M., Monson, R. R., Olivier, D. C., Sobol, A. M., \& Leighton, A. H. (1987). Affective disorders and mortality. Archives of General Psychiatry, 44, 473-480.

Musselmann, D. L., Evans, D., \& Nemeroff, Ch. B. (1998). The relationship of depression to cardiovascular disease. Archives of General Psychiatry, 55, 580-592.

Oman, D, \& Thoresen, C. E. (2003). Without spirituality does critical health psychology risk fostering cultural iatrogenesis. Journal of Health Psychology, 8, 223-229.

Piko, B. F. (2004). Interplay between self and community: A role for health psychology in Eastern Europe's public health. Journal of Health Psychology, 9, 111-120.

Piko, B. F., \& Fitzpatrick, K. M. (in press). Substance use, religiosity and other protective factors among Hungarian adolescents. $A d$ dictive Behaviors.

Powell, L. H., Shahabi, L., \& Thoresen, C. E. (2003). Religion and spirituality: Linkages to physical health. American Psychologist, 58, 36-52.

Pratt, L. A., Ford, D. E., Crum, R. M., Armenian, H. K., Gallo, J. J., \& Eaton, W. W. (1996). Depression, psychotropic medication and risk of myocardial infarction. Prospective data from the Baltimore ECA follow-up. Circulation, 94, 3123-3129.

Rahe, R. H., Taylor, C. B., Tolles, R. T., Newhall, L. M., Veach, T. V., \& Bryson, S. (2002). A novel stress and coping workplace program reduces illness and health care utilization. Psychosomatic Medicine, 64, 278-286.

Rahe, R. H., \& Tolles, R. L. (2002). The Brief Stress and Coping Inventory: A useful stress management instrument. International Journal of Stress Management, 9(2), 61-70.

Rahe, R. H., Veach, T. L., Tolles, R. L., \& Murakami, K. (2000). The stress and coping inventory: An educational and research instrument. Stress Medicine, 16, 199-208. 
Rózsa, S., Kő, N., Csoboth, Cs., Purebl, Gy.,5 Beöthy-Molnár, A., Szebik, I., Réthelyi, J., Skrabski, Á., Szádóczky, E., \& Kopp, M. (in press). Stress and coping. First results with the Hungarian version of Stress and Coping Questionnaire of Richard Rahe. Alkalmazott Pszichológia. (in Hungarian)

Rózsa, S., Purebl, Gy., Susánszky, É., Kő, N., Szádóczky, E., Réthelyi, J., Danis, I., Skrabski, Á., \& Kopp, M. (in press). Dimensions of coping, Hungarian version of the Ways of Coping Questionnaire. Alkalmazott Pszichológia. (in Hungarian)

Rózsa, S., Réthelyi, J., Stauder, A., Susánszky, É., Mészáros, E., Skrabski, Á., \& Kopp, M. (2003). The health status of the Hungarian population according to the Hungarostudy 2002: The methods and the characteristics of the representative sample. Psychiatria Hungarica, 18, 83-94. (in Hungarian)

Rózsa, S., Szádóczky, E., \& Füredi, J. (2001). Psychometric properties of the Hungarian version of the shortened Beck Depression Inventory. Psychiatria Hungarica, 16, 384-402. (in Hungarian)

Schwarzer, R. (1993). Measurement of perceived self-efficacy. Psychometric scales for cross-cultural research. Berlin, Germany: Freie Universität Berlin.
Seligman, M., \& Csikszentmihályi, M. (2000) Positive psychology: An introduction. American Psychologist, 55, 5-14.

Skrabski, Á., Kopp, M., \& Kawachi, I. (2003). Social capital in a changing society: Cross sectional associations with middle aged female and male mortality rates. Journal of Epidemiology and Community Health, 57, 114-119.

Skrabski, Á., Kopp, M., \& Kawachi, I. (2004). Social capital and collective efficacy in Hungary: Cross-Sectional associations with middle-aged female and male mortality rates. Journal of Epidemiology and Community Health, 58, 340-345.

SPSS. (1997). The SPSS base 7, 5 for Windows user's guide. Chicago: SPSS, Inc.

SPSS. (1999). SPSS base 9.0 user's guide. Chicago: SPSS, Inc.

SPSS. (1999). SPSS regression models 9.0. Chicago: SPSS, Inc.

Wannamethee, G., \& Shaper, A. G. (1991). Self-assessment of health status and mortality among middle aged British men. International Journal of Epidemiology, 20, 239-245.

World Health Organization. (2001). The world health report, mental health: New understanding, new hope. 